\title{
MODEL RESOLUSI KONFLIK MEMBANGUN KEMAMPUAN PENYELESAIAN KONFLIK SISWA SEKOLAH DASAR
}

\author{
Sa'odah $^{1}$, Bunyamin Maftuh ${ }^{2}$, Sapriya $^{3}$ \\ ${ }^{1}$ Universitas Muhammadiyah Tangerang \\ 1,2,3 Universitas Pendidikan Indonesia \\ ${ }^{1}$ saodah@upi.edu
}

\begin{abstract}
This article aims to discuss the importance of implementing conflict resolution models in elementary schools to improve conflict resolution skills in elementary school students. The ability to resolve conflicts does not occur naturally for students. The ability to resolve conflicts is needed for students in real life, but is often neglected in the learning process. Students' conflict resolution abilities can be developed through a learning process using a conflict resolution model. This model has the advantage that students can solve problems, think critically, communicate, and have better interpersonal skills. The research method used is a literature study to describe the application of the conflict resolution model based on several experts and based on supporting reference studies. The results of the study that some conflicts that occur among elementary school students are an indicator that they do not have good or constructive conflict resolution skills, conflict resolution abilities in elementary school students can be facilitated by educators and can also be done through peers. Several results of research studies show that the application of conflict resolution learning models can significantly increase students' knowledge and attitudes towards conflict resolution, and there is a constructive increase in conflict resolution skills.
\end{abstract}

Keywords: conflict resolution model; conflict resolution skills; elementary school

\begin{abstract}
Abstrak
Artikel ini bertujuan untuk membahas pentingnya penerapan model resolusi konflik di sekolah dasar untuk meningkatkan kemampuan penyelesaian konflik pada peserta didik sekolah dasar. Kemampuan menyelesaikan konflik tidak terjadi secara alamiah dimiliki peserta didik. Kemampuan menyelesaikan konflik dibutuhkan bagi peserta didik dalam kehidupan nyata, namun seringkali terabaikan dalam proses pembelajaran. Kemampuan menyelesaikan konflik peserta didik dapat dikembangkan melalui proses pembelajaran dengan menggunakan model resolusi konflik. Model ini memiliki keunggulan dimana peserta didik dapat memecahkan masalah, berfikir kritis, komunikasi, dan keterampilan interpersonal dengan lebih baik. Metode penelitian yang digunakan adalah studi kepustakaan untuk mendeskripsikan penerapan model resolusi konflik berdasarkan beberapa ahli dan berdasarkan studi referensi pendukung. Hasil dari kajian bahwa beberapa konflik yang terjadi di antara peserta didik sekolah dasar menjadi indikator bahwa mereka tidak memiliki keterampilan penyelesaian konflik secara baik atau konstruktif, kemampuan resolusi konflik pada peserta didik sekolah dasar dapat di fasilitatori oleh pendidik dan dapat pula dilakukan melalui teman sebaya. Beberapa hasil kajian penelitian menunjukkan bahwa penerapan model pembelajaran resolusi konflik secara signifikan efektif dapat meningkatkan pengetahuan dan sikap peserta didik terhadap resolusi konflik, dan terjadi peningkatan konstruktif keterampilan resolusi konflik.
\end{abstract}

Kata Kunci: kemampuan penyelesaian konflik; model resolusi konflik; sekolah dasar

\begin{tabular}{llll} 
Received & $: 2021-01-21$ & Approved & $: 2021-07-22$ \\
Reviesed & $: 2021-07-20$ & Published & $: 2021-07-31$ \\
\hline
\end{tabular}

Jurnal Cakrawala Pendas is licensed under a Creative Commons Attribution-

ShareAlike 4.0 International License. 


\section{Pendahuluan}

Konflik dapat terjadi di semua kalangan, termasuk konflik pada anak usia sekolah dasar. Fakta konflik yang terjadi pada peserta didik sekolah dasar di Indonesia dalam berbagai media informasi sungguh sangat memperihatinkan. Jumat,18 September 2015 pukul 10.00 terjadi perkelahian yang berujung pada tewasnya peserta didik kelas 2 NA (8) SDN 07 Pagi Kebayoran Lama Utara, berawal dari sebuah ejekan pada saat perlombaan menggambar (Aziza, 2015). Hal serupa terjadi Pada tanggal 10 Agustus 2017 SR, peserta didik Kelas 2 di salah satu SDN di Longwang, desa Hegarmanah, Kabupaten Caint, Kabupaten Sukabumi, Jawa Barat, meninggal setelah bertarung dengan temannya, konon akar masalahnya yakni karena bullying atau saling ejek (Ika, 2017). Korban Bullying juga terjadi di daerah Kademangan BSD, tepatnya pada hari Sabtu 19 November 2016, setelah sekolah, Aldi dilecehkan oleh teman-temannya, sebuah sekolah di Mathlaul Anwar BSD Aldi dipaksa untuk berenang ke dalam empang dengan kedalaman hampir 3 meter bahkan nyaris merengut nyawa anak yang masih di sekolah dasar. (Banu, 2016).

Budaya kekerasan (destruktif), seperti perkelahian di antara peserta didik, maupun antar warga marak terjadi. Sabtu (27/2/2016) terjadi tawuran antarpelajar di Kabupaten Tangerang dengan tertangkapnya tujuh pelajar pelaku tawuran oleh petugas Polsek Cikupa, Satu dari tujuh pelajar tersebut ternyata masih peserta didik SD, satu lainnya masih SMP (Bermana, 2016). Lebih memprihatinkan lagi yaitu Jumat, 31 Maret 2017 Unit Polisi Layanan Publik Tangerang (Satpol PP) mendapat seorang peserta didik yang ditemukan membawa benda-benda tajam dalam bentuk sabit di Taman Potret, Tangerang Kota, ternyata peserta didik itu duduk di tingkat sekolah dasar (SD) (Khanif, 2017). Kejadian serupa terjadi pula di Purwakarta pada hari Jumat, 20 April 2018 pukul 10.00 WIB Polisi menangkap belasan peserta didik sekolah dasar membawa berbagai jenis senjata runcing ke jam kelas. Mereka ingin menyerang berbagai peserta didik sekolah dasar. Beruntung aksinya dapat dicegah oleh warga dengan Babinsa dan Bombinkammtibmas. Dari tangan peserta didik sekolah dasar ini, diamankan barang bukti berupa 4 parang, 5 celurit, 2 golok, 2 gesper, 2 besi tumpul, dan 1 gir motor diikat gesper (Lia, 2018). Dan diyakini masih banyak kasus yang terjadi pada peserta didik sekolah dasar.

Jika kita memperhatikan situasi saat ini, iklim sekolah tidak selalu damai dan aman. Bahkan, konflik sering terjadi di sekolah dan jam di luar kelas. Apakah dalam bentuk konflik sederhana atau lebih serius. Konflik di sekolah dapat terjadi dalam berbagai bentuk, baik horizontal maupun vertikal. Konflik horizontal seperti konflik antara peserta didik (konflik interpersonal), kelompok peserta didik di sekolah dan peserta didik sekolah dan peserta didik di sekolah lain. Hasil penelitian (Ernawati \& Yuliati, 2019) menyatakan bahwa penyebab konflik berupa ejekan seorang peserta didik kepeserta didik lainnya yang berujung perkelahian, pada umumnya peserta didik yang terlibat dalam konflik adalah seorang peserta didik yang prestasi akademiknya kurang dan tidak berpartisipasi dalam kegiatan di luar akademisi mereka sesuai dengan bakat dan minat mereka.

Keterampilan menyelesaikan konflik antar peserta didik sekolah dasar sudah pasti berbeda-beda. Beberapa konflik yang terjadi di antara peserta didik sekolah dasar menjadi indikator bahwa mereka tidak memiliki keterampilan penyelesaian konflik secara baik atau konstruktif (Dewi \& Maftuh, 2020) (Patra Ritiauw, Maftuh, \& Malihah, 2018) (Türk, 2017); menunjukkan bahwa penerapan model pembelajaran resolusi konflik secara signifikan efektif dapat meningkatkan pengetahuan dan sikap peserta didik terhadap resolusi konflik, dan terjadi peningkatan konstruktif keterampilan resolusi konflik. Hal senada diungkapkan (Akgun \& Araz, 2014)(Sagkal, Turnuklu, \& Totan, 2016) disamping dapat meningkatkan keterampilan resolusi konflik secara konstruktif, pendidikan resolusi konflik dapat mengurangi tingkat agresi reaktif dan proaktif. Sedangkan berdasarkan hasil penelitian (Hidayah, Suyitno, \& Sari, 2019) bahwa kemampuan resolusi konflik pada peserta didik sekolah dasar dapat di fasilitatori oleh 
pendidik, teman sebaya (Burton, 2012). Untuk mengatasi dan mengurangi konflik yang terjadi di sekolah maka diperlukan peran sekolah dan pendidik agar peserta didik dapat memiliki keterampilan penyelesaian konflik yang baik.

\section{Metode Penelitian}

Metode penelitian yang digunakan adalah studi kepustakaan untuk mendeskripsikan penerapan model resolusi konflik berdasarkan beberapa ahli dan berdasarkan studi referensi pendukung. Kajian pustaka berupa ringkasan tertulis mengenai artikel dari jurnal, buku dan dokumen lain yang mendeskripsikan teori serta informasi baik masa lalu maupun saat ini, mengorganisasikan pustaka ke dalam topik dan dokumen yang dibutuhkan untuk penelitian. Seperti yang diungakapkan oleh (Cresswell, 2010) bahwa dalam penelitian pendidikan, peneliti mementingkan kajian pustaka yang diambil dari artikel pada jurnal, namun demikian peneliti juga membutuhkan informasi lain yang diambil dari makalah konferensi, buku dan dokumen pemerintah.

\section{Hasil dan Pembahasan}

\section{Model Resolusi Konflik}

Secara etimologis, konflik (conflict) berasal dari bahasa Latin yang berarti saling memukul. Konflik juga ditafsirkan sebagai tindakan salah satu pihak yang mengakibatkan pemblokiran, menghambat atau menjengkelkan bagian lain di mana hal ini dapat terjadi antara kelompok masyarakat atau dalam hubungan kehidupan. Ini sejalan dengan pendapat Morton Deutsch, pelopor pendidikan resolusi konflik yang menunjukkan bahwa dalam konflik, interaksi sosial antara individu atau kelompok lebih dipengaruhi oleh perbedaan daripada dengan persamaan (Maftuh, 2005). Sejalan dengan hasil penelitian Visinki (1995) menyebutkan bahwa metode untuk mengatasi konflik adalah persaingan. Dalam konflik, interaksi sosial antara individu atau kelompok lebih dipengaruhi oleh perbedaan daripada dengan kesetaraan (Akgun \& Araz, 2014). Dalam situasi konflik, seseorang dapat menghindari, mengalahkan atau bahkan menghancurkan pihak lain.

Konflik adalah salah satunya elemen alami dari lingkungan sosial (Bayraktar \& Yilmaz, 2016). Konflik didefinisikan sebagai interaksi antara dua bagian atau lebih yang saling bergantung, tetapi dipisahkan oleh perbedaan dalam tujuan di mana setidaknya satu dari bagian-bagian ini mengetahui perbedaan ini dan mengambil tindakan terhadap tindakan.

Kapusuzoglu (2010) menyatakan bahwa dalam mengatasi konflik diperlukan metode sebagai upaya untuk menyelesaikan konflik adalah sebagai berikut: a) metode menang-kalah, dimana pemenang mengambil semua posisi biasanya fokusnya adalah memenangkan konflik dengan biaya, daripada mencari solusi yang paling tepat untuk semua orang yang peduli; b) metode akomodasi, merupakan kebalikan dari kompetisi yaitu pendekatan kalah/menang; c) metode penghindaran, di mana kedua pihak dalam konflik menarik diri sebagai hasil kalah/ kalah dalam mengelola konflik karena tidak ada pihak yang mampu menangani masalah ini, apalagi mengelola atau mengatasinya; d) metode kolaborasi, yang biasanya dianggap sebagai metode terbaik untuk mengatasi konflik atau disebut pendekatan win/win, dimana kedua belah pihak jujur mencari alasan baru dan umum yang lebih tinggi untuk menyelesaikan konflik; e) metode resolusi kompromikonflik yang melibatkan negosiasi dan fleksibilitas tingkat tinggi atau disebut sebagai posisi menang/ kalah-menang/ kalah karena kedua pihak dalam konflik akan mendapatkan sebagian dari apa yang mereka inginkan, metode ini dianalisis secara teoritis dan praktis.

Resolusi konflik adalah kerangka kerja intelektual umum untuk memahami apa yang terjadi dalam konflik dan bagaimana melakukan intervensi di dalamnya. Memahami dan intervensi dalam konflik tertentu membutuhkan pengetahuan khusus tentang partaipartai terhadap konflik, konteks sosial, aspirasi mereka, orientasi konflik, norma sosial, dll. Keterlibatan penting kerjasama persaingan adalah koperasi atau gain untuk menyelesaikan konflik dengan sangat memfasilitasi resolusi konstruktif, sementara orientasi yang 
kompetitif atau tahan lama mencegahnya. Lebih mudah untuk mengembangkan dan memilih sikap menang jika Anda memiliki dukungan sosial untuknya. Dukungan sosial dapat berasal dari teman, rekan kerja, wirausahawan, media atau komunikasi (Coleman et all, 2016).

Model resolusi konflik adalah kemampuan dan keterampilan peserta didik untuk mengatasi dan menyelesaikan dan mengambil langkah-langkah pada berbagai fenomena sosiokultural dan masalah yang terjadi di komunitas mereka (lokal, regional, nasional dan internasional) yang didukung oleh nilai-nilai sosial dan budaya komunitas tempat mereka tinggal dan berkembang. Sedangkan menurut (Rodiyah, Lasmawan, \& Dantes, 2018) menyatakan bahwa orang yang tidak memiliki kecerdasan interpersonal dengan baik, umumnya cenderung tidak mampu mengelola dan menyesuaikan konflik dengan cara konstruktif. Model resolusi konflik sebagai model pembelajaran pada dasarnya adalah gerakan revolusioner interdisipliner dalam pembelajaran civic yang dikembangkan untuk merangsang dan mengeksplorasi hubungan antara satu sama lain, sekarang dan masa depan dalam konflik multidimensi sehingga setiap orang berkewajiban untuk memiliki pengetahuan dan keterampilan berakhir. Konflik di komunitas untuk kesejahteraan umat manusia. (NCSS, 2000). Dengan demikian Model resolusi konflik adalah model pembelajaran yang dikembangkan untuk mempraktikkan kemampuan dan keterampilan peserta didik untuk mengatasi dan menyelesaikan dan mengambil tindakan pada berbagai fenomena dan masalah sosiokultur yang terjadi di lingkungan masyarakat.

Model pengajaran resolusi konflik terinspirasi oleh sudut pandang progresivisme. Progresivisme berkembang dari filosofi pragmatis, sebagai reaksi terhadap pemikiran prenealisme dalam pendidikan. Gerakan progresif tumbuh dari pemikiran politik terhadap kaum progresif, seperti Robert Lafollette, Theodore Roosevelt, dan Woodrow Wilson. Progresrasi dianggap sebagai pergerakan reformasi kontemporer di bidang pendidikan, sosial dan politik (Ornstein dan Hunkins, 2018). Dengan penerapan pendidikan filsafat, pendidikan dapat memberikan yang bermanfaat bagi peserta didik, terutama terhadap masalah aktual yang ditemukan di lingkungan masyarakat. Progresivisme sebagai sarana atau alat yang disiapkan untuk mengembangkan kemampuan peserta didik sehingga mereka bertahan hidup semua tantangan kehidupan mereka yang hampir selalu berlangsung (Muhmidayeli, 2011). Progresivisme menekankan bagaimana berpikir, bukan apa yang harus dipikirkan. Keterampilan menurut pemikiran progresif adalah pemecahan masalah dan metode ilmiah. Sekolah berperan dalam membina kerjasama, disiplin diri, dan mentransmisikan budaya masyarakat (Ornstein \& Hunkins, 2018).

Adapun ciri-ciri model pembelajaran resolusi konflik dalam pembelajaran meliputi langkah-langkah sebagai berikut: 1) Identifikasi, 2) Eksplorasi, 3) Eksplanasi, 4) Negosiasi Konflik, dan 5) Resolusi Konflik (Maftuh, 2005). Pakar dan praktisi pendidikan melakukan pendidikan resolusi konflik di lembaga-lembaga pendidikan melalui berbagai pendekatan. (Crawford dan Bodine, 1996) merumuskan empat macam pendekatan dalam pendidikan resolusi konflik, diatarannya yaitu: 1) Process curriculum approach (pendekatan proses kurikulum); 2) Mediation program approach (Pendekatan Mediasi Program); 3) Peaceable classroom approach (pendekatan kelas damai); dan 4) Peaceable school approach (pendekatan sekolah damai).

\section{Kemampuan Penyelesaian Konflik}

Kemampuan resolusi konflik seseorang menurut (Scannell, 2010: 8) dapat dipengaruhi oleh beberapa aspek sehingga individu dapat memahami dan meresolusi sebuah konflik dengan baik, diantaranya yaitu : a) keterampilan berkomunikasi, b) kemampuan menghargai perbedaan, c) kepercayaan terhadap sesama dan d) terdapat kecerdasan emosi. Menurut Bodine and Crawford (Jones dan Kmitta, 2001) ada beberapa macam kemampuan yang sangat penting untuk menumbuhkan inisiatif dalam resolusi konflik diantaranya yaitu: a) kemampuan orientasi, b) kemampuan persepsi, c) 
kemampuan emosi, d) kemampuan komunikasi, e) kemampuan berfikir kreatif dan f) kemampuau berfikir kritis.

Dari pendapat ahli di atas dapat diketahui bahwa dalam resolusi konflik diperlukan kemampuan-kemampuan untuk mencari penyelesaian konflik secara konstruktif, adapun kemampuan yang dimaksud yaitu kemampuan orientasi, kemampuan persepsi, kemampuan emosi, kemampuan komunikasi, kemampuan menghargai perbedaan, kemampuan berfikir kreatif dan kemampuan berfikir kritis.

Kemampuan penyelesaian konflik dapat dilakukan melalui beberapa strategi, diantaranya dengan 1) negosiasi, yaitu memecahkan konflik oleh pihak-pihak yang berkonflik sendiri, 2) Mediasi, menyelesaikan konflik melalui bantuan pihak ketiga yang netral, dan 3) Arbitrasi atau ajudikasi, menyelesaikan konflik melalui bantuan pihak ketiga yang mempunyai otoritas untuk menentukan hasil atau solusi konflik.

Beberapa hasil penelitian yang sudah dilakukan terkait model resolusi konflik yaitu penelitian (Hidayah et al., 2019) menunjukan bahwa kemampuan resolusi konflik pada siswa Sekolah Dasar di fasilitatori oleh guru. Selain itu, terdapat pola resolusi konflik siswa yaitu, penenangan, mengambil tanggung jawab, pemilihan solusi dan terakhir adalah penyelesaian. Sedangkan hasil dari penelitian (Rusminiati, Putra, \& Abadi, 2014) model pembelajaran resolusi konflik berbasis masalah kontekstual dapat berpengaruh terhadap hasil belajar peserta didik Kelas V SD, sejalan dengan penelitian dari (Rodiyah et al., 2018) bahwa dengan menggunakan model pembelajaran resolusi konflik dapat berpengaruh terhadap sikap sosial dan hasil belajar IPS peserta didik Kelas V SD, sedangkan (Maftuh, 2010) menyatakn bahwa memperkuat peran IPS dalam dilakukan dengan membelajarkan keterampilan sosial dan resolusi konflik. Sejalan dengan penelitian-penelitian di atas (Ernawati \& Yuliati, 2019) menyatakan bahwa dalam pemecahan konflik siswa sekolah dasar, dapat dilakukan dengan menggunakan strategi/model resolusi konflik.

\section{Kesimpulan}

Berdasarkan hasil kajian yang telah dipaparkan di atas, bahwa model resolusi konflik dapat mengembangkan kemampuan penyelesaian konflik secara destruktif. Kemampuan penyelesaian konflik peserta didik dapat dikembangkan dalam proses pembelajaran melalui langkah-langkah pembelajaran model resolusi konflik. Salah satu karakteristik model tersebut yaitu disajikan konflik sebagai fokus dalam pembelajaran. Konflik yang disajikan bersifat kontekstual yang ada di sekitar peserta didik. Dengan semakin cepat anak-anak diperkenalkan pada pengetahuan tentang konflik dan cara-cara penyelesaian serta mempraktikkan keterampilan yang terkait dengannya, semakin besar kemungkinan mereka akan menjadi agen perubahan positif di masa depan. Sekolah perlu memikirkan cara-cara yang menarik dan menyenangkan dalam membantu menyelesaikan konflik yang terjadi di sekolah. Seseorang dikatakan memiliki kemampuan penyelesaian konflik yang baik, apabila peserta didik mampu memberikan penyelesaian secara konstruktif, adapun kemampuan yang dimaksud yaitu kemampuan orientasi, kemampuan persepsi, kemampuan emosi, kemampuan komunikasi, kemampuan menghargai perbedaan, kemampuan berfikir kreatif dan kemampuan berfikir kritis. Dengan demikian penerapan model resolusi konflik sangat penting diterapkan dalam proses pembelajaran karena akan membawa peserta didik mampu memecahkan permasalahan yang muncul dalam dunia nyata peserta didik.

\section{Daftar Pustaka}

Akgun, S., \& Araz, A. (2014). The effects of conflict resolution education on conflict resolution skills, social competence, and aggression in Turkish elementary school students. Journal of Peace Education, 11(1), 30-45. https://doi.org/10.1080/17400201.2013.777898

Aziza, K. S. (2015). Berawal dari Ejekan, Perkelahian Siswa Kelas 2 SD Itu Berujung Kematian. 
https://megapolitan.kompas.com/read/2015/09/19/17421981/Berawal.dari.Ejekan.Pe rkelahian.Siswa.Kelas.2.SD.Itu.Berujung.Kematian

Banu, S. (2016). Anak SD di Tangerang Nyaris Tewas Tenggelam Karena dibully oleh Temannya. Retrieved from The Asian Parent Indonesia.com website: https://id.theasianparent.com/anak-sd-di-bsd-hampir-tenggelam-karena-dibullytemannya

Bayraktar, H. V., \& Yilmaz, K. Ö. (2016). Investigation of Primary School Teachers' Conflict Resolution Skills in Terms of Different Variables. Journal of Education and Training Studies, 4(9), 222-231. https://doi.org/10.11114/jets.v4i9.1741

Bermana, G. (2016). Tawuran Pelajar di Kabupaten Tangerang Libatkan Siswa SD. Retrieved from Banten Hits website: https://megapolitan.kompas.com/read/2015/09/19/17421981/Berawal.dari.Ejekan.Pe rkelahian.Siswa.Kelas.2.SD.Itu.Berujung.Kematian

Burton, B. (2012). Peer teaching as a strategy for conflict management and student reengagement in schools. Australian Educational Researcher, 39(1), 45-58. https://doi.org/10.1007/s13384-011-0046-4

Coleman, P.T., (eds). (2016). Resolusi Konflik Teori dan Praktek. Bandung: Nusa Media.

Crawford, D. \& Bodine, R. (1996). Conflict resolution education: a guide to implementing programs in schools, youth-serving organizations, and community and juvenile justice settings. (Program Report). US Department of Justice \& US Department of Education.

Creswell, John W. (2010). Research Design: Qualitative, Quantitative, and mixed methods Approaches, 3th, terjemahan Achmad Fawaid. Yogyakarta.

Dewi, S. M., \& Maftuh, B. (2020). The Value of "Silih Asah, Silih Asih, Silih Asuh" in Conflict Resolution Education at Elementary Schools. 422(Icope 2019), 258-261. https://doi.org/10.2991/assehr.k.200323.130

Ernawati, \& Yuliati, A. (2019). Strategi Pemecahan Konflik Siswa Sekolah Dasar Di Kabupaten Bangkalan. 3(1), 211-225.

Hidayah, Y., Suyitno, S., \& Sari, L. R. (2019). Analisis Kemampuan Resolusi Konflik Siswa Sekolah Dasar. JKPD (Jurnal Kajian Pendidikan Dasar), 4(1), 607. https://doi.org/10.26618/jkpd.v4i1.1726

Ika. (2017). Keluarga Korban dan Pelaku Perkelahian Siswa SD Trauma Berat. Tangerang Ekspres. Retrieved from http://www.tangerangekspres.co.id/2017/08/10/keluargakorban-dan-pelaku-perkelahian-siswa-sd-trauma-berat/

Jones, T.S., \& Kmitta, D. (2001). School Conflict Management: Evaluating Your Conflict Resolution Education Program. Ohio Department of Education and the Ohio Commission on Dispute Resolution and Conflict Management.

Kapusuzoglu, S. (2010). An investigation of conflict resolution in educational organizations. African Journal of Business Management Vol.4 (1), pp. 096- 102, January, 2010 ISSN 1993-8233. Available [online] at http://www.academicjournals.org/AJBM.

Khanif. (2017). Miris, Murid SD Kedapatan Bawa Sajam. Berita online tersedia di https://www.detakbanten.com/today/7964-miris-murid-sd-kedapatan-bawa-sajam.

Lia. (2018). Miris, siswa SD di Purwakarta kedapatan bawa sajam diduga mau tawuran merdeka com. Retrieved from https://www.merdeka.com/peristiwa/miris-siswa-sd-dipurwakarta-kedapatan-bawa-sajam-diduga-mau-tawuran.html

Maftuh, B. (2005) Pendidikan Resolusi Konflik: Membangun Generasi Muda yang Mampu Menyelesaikan Konflik Secara Damai. Bandung: Program Pendidikan Kewarganegaraan, Universitas Pendidikan Indonesia.

Maftuh, B. (2010). Memperkuat Peran IPS dalam Membelajarkan Keterampilan Sosial dan Resolusi Konflik. 1-32. Retrieved from http://file.upi.edu/Direktori/PIDATO/3._PIDATO_PENGUKUHAN_BUNYAMIN. pdf

National Counsil for the Social Studies (NCSS). (2000). National Standards for Social 
Studies Teachers Volume 1. Washington: National Council for the Social Studies.

Ornstein, A. C. \& Hunkins, F. P. (2018). Th edition Global Edition Curriculum: Foundations, Principles, and Issues. London: Pearson Education.

Patra Ritiauw, S., Maftuh, B., \& Malihah, E. (2018). Model of Conflict Resolution Education Based on Cultural Value of qPelaq in Social Studies Learning. 147(Icsse 2017). https://doi.org/10.2991/icsse-17.2018.66

Rodiyah, H., Lasmawan, W., \& Dantes, N. (2018). Pengaruh Model Pembelajaran Resolusi Konflik Terhadap Sikap Sosial Dan Hasil Belajar Ips Kelas V Sd Gugus 2 Selong Lombok Timur. Jurnal DIDIKA: Wahana Ilmiah Pendidikan Dasar, 4(1), 24. https://doi.org/10.29408/didika.v4i1.1197

Rusminiati, N. P. I., Putra, M., \& Abadi, I. G. S. (2014). Model Pembelajaran Resolusi Konflik Berbasis Masalah Kontekstual Berpengaruh Terhadap Hasil Belajar Siswa Kelas V SD Gugus 1 Abiansemal. Jurnal Mimbar PGSD Universitas Pendidikan Ganesha, 2(1).

Sagkal, A. S., Turnuklu, A., \& Totan, T. (2016). Barış eğitiminin saldırganlık üzerindeki etkileri: Karma yöntem bir çalışma. Egitim Arastirmalari - Eurasian Journal of Educational Research, (64), 45-68. https://doi.org/10.14689/ejer.2016.64.3

Scannell, M. (2010). The Big Book of Conflict Resolution Games: Quick, Effective Activities to Improve Communication, Trust and Collaboration. Retrieved from https://books.google.com/books?id=DZnA4SAPGwQC\&pgis=1

Türk, F. (2017). Evaluation of the Effects of Conflict Resolution, Peace Education and Peer Mediation: a Meta-Analysis Study. International Education Studies, 11(1), 25. https://doi.org/10.5539/ies.v11n1p25.

Visinki (1995). Coping with conflict in the workplace. TJCTA Conference for Faculty Leaders, Austin. Ed. Burnside, 2008. 